\title{
A STOIC REMEDY FOR DISEASED EARS
}

\section{(PERSIUS 5.86) 1}

\section{J.C. Zietsman, University of Stellenbosch}

In his fifth satire Persius uses the metaphor of the cleansed ear (aurem mordaci lotus aceto, line 86) to convey his message that Stoicism should be used as the remedy for cleansing the diseased ears of mankind. This metaphor also appears in Satire 1 and is there interwoven with an ear motif ridiculing contemporary literary style and judgement.

The purpose of this paper is to study the poet's use of the ear motif and metaphor in Satires 1 and 5 and to ascertain the importance which Persius attached to these references.

\section{A broad outline of Satire 1}

$\begin{array}{ll}\text { Lines 1-12 } & \text { Introduction } \\ \text { Lines 13-106 } & \text { Literary and moral rottenness } \\ \text { Lines 107-134 } & \text { Epilogue }\end{array}$

Persius' first satire is an attack on contemporary literature and morals. After introducing his satire (lines 1-12) by justifying his writing of satire because contemporary standards of judgement are worthless, the satirist consistently develops the twin themes of literary and moral rottenness in the main part of the satire (lines 13-106) and establishes his independence from the prevailing Hellenism of the day.

His implication is that the decline from the standards of the best of Roman literature is symptomatic of a collapse in Roman morality. By interweaving repeated sexual and eating metaphors, Persius colours his picture of the moral and literary depravity of Neronian Rome (Morford 1984:36-37).

In the epilogue of the satire (lines 107-134) the poet returns to the central figure of the introduction, namely the satirist himself. Persius is warned by an interlocutor in the role of a concerned friend that the poet would do better not to be so critical and persist with a genre (i.e. satire) that can only cause trouble for the poet who runs the risk of alienating Roman society (Lee and Barr 1987:83)2

1 An abridged version of this article was presented at the 20th biennial conference of CASA, held at the University of the Witwatersrand, January 1993.

2 The imaginary interlocutor sometimes (although not here) suggests safer or more profitable subjects. Such a figure occurs in Lucilius (Warmington, R.O.L. 713-714), Horace is so advised in Sat. 2.1.60-61, and Juvenal writes in the same vein in Sat. 1.155-157, 160-161. 
The interlocutor's question raises a standard subject in the satiric tradition which both Lucilius and Horace had dealt with. Persius casts the question in phrases appropriate to his satire (lines 107-108) when the interlocutor asks:

'sed quid opus teneras mordaci radere uero

"But what is the point of grating tender ears with biting truths?"

The phrase teneras ... auriculas (literally "soft little ears") is the poet's first reference to the metaphor of the cleansed ear. Scorn for the effeminacy of Roman society has run through the main part of the poem (Morford 1984:37; Reckford 1962:480-481). Especially in conjunction with the epithet teneras, the diminutive noun auriculas also expresses scorn, for teneras suggests specific weaknesses:

Firstly: an ear is tender when hurt by rough or vigorous poetry, when it can only endure the "smooth-flowing" line.

Secondly: an ear is tender when it is offended by the biting truth - these auriculas are not used to hearing harsh truths.

Thirdly: tender ears more than likely belong to a tender person in a tender, i.e. effeminate society.

Effeminate poetry and weak criticism are symptoms of a general emasculation.

The phrase mordaci radere uero is a complex one. Both mordaci and radere have a medical connotation: mordaci is used in its literal sense of "stinging, astringent" and refers to the cleansing agent used in the procedure of aural cleansing, as in Persius 5.86, aurem mordaci lotus aceto ("an ear well-washed with biting vinegar"), while radere may signify a medical operation although actual surgery is not envisaged here (Harvey 1981:47). Celsus, the encyclopaedist who lived during the reign of Tiberius, noted that physicians usually treated deafness with vinegar (Celsus De Med. 6.7.2f., [sordes aurium] si durae sunt, acetum et cum eo nitri paulum coiciendum est). The notion seems to have been that the fumes of heated vinegar would make the hearing sharp and quick (Pretor 1907:21). For Persius, the truth (mordaci ... uero) becomes, as it were, stinging drops for cleansing the ear (Lee and Barr 1987:83).

Viewed another way, however, the expression mordaci radere uero contains no metaphor: mordaci is then used in its received extended sense of "biting, caustic", cf. e.g. Ov. Tr. 2.563, mordaci ... carmine, while radere means "offend", cf. Quint. 3.1.3, aures ... delicatas raderet. 
The metaphor of the cleansed ear actually continues the motif of the ears which was first introduced at line 22:

$\begin{array}{ll}\text { tunc neque more probo uideas nec uoce serena } & 19 \\ \text { ingentis trepidare Titos, cum carmina lumbum } & 20 \\ \text { intrant et tremulo scalpuntur ubi intima uersu. } & 21 \\ & \\ \text { tun, uetule, auriculis alienis colligis escas, } & 22 \\ \text { articulis quibus et dicas cute perditus 'ohe'? } & 23 \\ & \\ \text { "Then you might see the sturdy citizens quivering in unseemly } \\ \text { style and with unsteady voice as the poems enter their loins and as } \\ \text { their inmost parts are tickled by the trembling verse. Are you, old } \\ \text { man, composing for others.' ears titbits to which you, with your } \\ \text { ruined joints and skin, would say, 'Enough'?" }\end{array}$

These lines serve to expose the reciter as an homosexual physically wrecked by his vicious habits (articulis ... cute perditus), supplying his audience with a literary form of his once favoured vice (Harvey 1981:23). The effect of contemporary poetry upon the audience of Roman aristocrats is to be expected (Morford 1984:32). The poems are pictured as a sexual organ, entering and stimulating the inmost parts of the audience (lines 19-21).

Ambiguous vocabulary combines literary and sexual imagery. The mutual gratification of the effeminate poet and the depraved audience reaches its climax in lines 22-23: since the poet is physically incapable of sexual gratification, his poems perform that task for his audience, who, in their turn, stimulate his lust for applause. Thus the act is consummated as poet and audience mutually indulge their desires, the one for praise, the other for sexual stimulation. The derogatory diminutive auriculis suggests a perverted standard of literary criticism and taste. Note that Persius is also employing imagery of perverted function: the ear is eating titbits. Literature has become a barren activity - its purpose is the gratification of debased lusts, and it is symptomatic of the moral rottenness of Rome.

The ear motif reappears in line 121 and follows Persius' appeal to the example of his predecessors (lines 114-118). Lucilius castigated society and Horace with his gentler criticism attacked every vice. Persius therefore claims the right to add to the tradition (lines 119-123) even if his satire is only a secret muttering (line 119). He will bury his secret discovery (note that he is again using a derogatory diminutive) when he says:

hic tamen infodiam. uidi, uidi ipse, libelle: auriculas asini quis non habet?

"Yet here I will bury it. I've seen it, my dear book, I've seen it with my own eyes: who hasn't got the ears of an ass?"

This reference completes the question left unfinished in line 8, nam Romae quis non - a, si fas dicere! -

"For who is there in Rome who hasn't - oh, if only I might say it!"

- but, noticing the false severity of adult Roman citizens (lines 9-11), the only thing the satirist can do, is to laugh (line 12), for Roman society prefers bad poets to true ones (lines 
4-5) and its scales of judgement are out of balance (lines 5-7).

Persius takes over the legend of King Midas of Phrygia, who judged Pan's outlandish music to be better than that of Apollo. The latter. punished Midas for his inept aesthetic judgement by giving him the ears of an ass. Only his barber discovered the truth about Midas' ears, and whispered the secret into a ditch he had dug. But reeds grew from the ditch and repeated the secret to the world at large (see Ovid Met. 11.92-193). In the role of Midas' barber, Persius buries his secret in his book: everyone has ass's ears. Like Midas, everyone in Rome is incapable of sound aesthetic judgement. In particular, Persius is hitting at the general lack of good literary taste. His book, like the ditch, fails to keep the secret (Harvey 1981:51).

The appropriateness of the reference in line 121 has been established by the intervening criticism of Roman society and literary activity. For Persius, lack of taste is a pointer to total moral abdication (Bramble 1974:137). This allusion to the barber's secret naturally suggests Nero, ${ }^{3}$ who spent much time and effort diluding himself about his literary abilities. We should not, however, think solely of Nero: Persius' point, after all, is that everyone has asses' ears. The disease is all too contagious (Reckford 1962:481).

The story of Midas may be foreshadowed by another reference to the ear motif in line 59,

manus auriculas imitari mobilis albas

"a hand quick to imitate white ass's ears."

Asses are not usually white (albas) in ancient authors (see T.L.L. sv asinus 791.25f.) but Ovid (Met. 11.176) mentions the white bristles (uillis albentibus) inside Midas' ass's ears and also their mobility. Persius may have this passage in mind. The context here portrays a patron taken in by flattery. He has a captive audience of clients too dependent on him for their victuals to tell him the truth about his poetry. Only the satirist dares call him a fool and a fathead. The clients, lacking the satirist's freedom, can only express themselves indirectly, in sign language and behind the patron's back: the "white ass's ears" symbolise the susceptibility of fools to flattery and their consequent deafness to the true criticism which they need (Reckford 1962:480).

Finally, Persius returns to the question of his audience (lines 123-134). Already in lines 17 he had dissociated himself from the society that he will criticise and whose vanity will be shown up in contrast to the integrity of the Stoic poet (Morford 1984:37-38).

Contemporary literary productions may be popular, but the satirist writes for the discerning few, whose "ears are well-steamed" from reading the masters of Greek Old Comedy (lines 123-125). Therefore, he states in line 126:

inde uaporata lector mihi ferueat aure

"Let my reader be one whose ear has been cleansed and kindled by such strains."

3 According to the scholiast and Vita, Persius originally wrote Mida rex, for which quis non was later substituted so as to expel what might be construed as an allusion to Nero. There is, however, no foundation for this. Admittedly, uidi, uidi (line 120) would go better with Mida rex habet than with quis non habet. But quis non picks up line 8 , and it is more effective if everyone at Rome is indicted, not merely Nero or a type (Harvey 1981:51). 
The ear that is well-steamed (uaporata ... aure) with the vapour of warm vinegar therefore "cleansed" or "refined" - is more receptive of instruction (Lee and Barr 1987:86) and understanding (Harvey 1981:53) and replaces the diseased ears (teneras ... auriculas, lines 107-108 and auriculas asini, line 121) of the Roman populace (Reckford 1962:479).

For the first time the word auris is not used in its diminutive form auricula: the satirist has listeners whose ears are healthy and able to appreciate his poetry. The common people (symbolised by auriculas asini, line 121) with their vulgar and childish sense of humour (lines 127-133), lack the sensitivity to appreciate intellectual effort. The wit of the satirist has a constructive moral purpose, but the humour of the crowd is uneducated and pointless. For these people the public gazette (edictum, line 134) and the Roman equivalent of a soap opera (Callirhoen, line 134) ${ }^{4}$ are at the appropriate cultural level. The satirist, it is implied, stands apart. If the discerning few, those with uaporata ... aure, will listen, that is fine, but in any case he will not compromise his independence.

To summarise: there are five references to ears in Satire 1. In four instances the diminutive of the noun is used to suggest derision for false aesthetic values. Only once, in line 126, does aure carry a positive connotation to convey the sense of a healthy and balanced literary judgement.

The metaphor of the cleansed ear will be continued in Satire 5 and will, as a result of the composition of the satire, receive much more prominence there than in Satire 1. (It should be noted that Persius elsewhere uses another metaphor, that of thirsty or hungry ears, to convey his attitude towards men who are too easily flattered. In Satire 2.29-30, aut quidnam est qua tu mercede deorum/emeris auriculas? pulmone et lactibus unctis? the poet criticises the fool who impiously treats the gods as if, like humans, they had ears to be flattered, and in Satire 4.50, nequiquam populo bibulas donaveris aures he indicates that the fool trusts in popular opinion rather than self-knowledge). 5

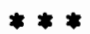

\section{A broad outline of Satire 5}

$\begin{array}{ll}\text { 1. } & \text { Lines } 1-29 \\ \text { 2. Lines } 30-51 \\ \text { 3. Lines } 52-72 \\ \text { 4. Lines } 73-131 \\ \text { 5. Lines } 132-191\end{array}$

Explanation of poetic principles

Explanation of philosophic foundations

Variety of human pursuits

Only the wise man is truly free

The fool is a slave of his passions

A wide range of subject matter, most importantly the programmatic statements on poetry and morality in the prologue and the first satire, is brought together in Persius' fifth satire. In the first part of the satire (lines 1-51) he is the pupil of Cornutus, learning the craft of poetry and a philosophy for life in harmonious friendship with his teacher (Zietsman 1991:94-103). He abandons this subordinate persona at line 52 and for the rest of the poem speaks as a graduate rather than a student.

4 The edictum is apparently some kind of public announcement and Callirhoe must be the title of a trashy play or mime on a par with the literary productions criticised by Persius and therefore suitable for the common crowd (Morford 1984:113). 
Having explained his poetic and philosophical foundations in lines 1-51, Persius uses the theme of the variety of human interests (lines 52-72) as a final preparation for his discussion (from line 73 onwards) of the famous Stoic paradox that only the wise man is free.

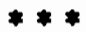

Although Cornutus has served his purpose as interlocutor in the first 51 lines of the satire, he is reintroduced in lines 62-65 together with his philosophy (fruge Cleanthea), ${ }^{6}$ where his devotion to philosophy is contrasted with the lusts and greed of other men as described in lines 52-61:

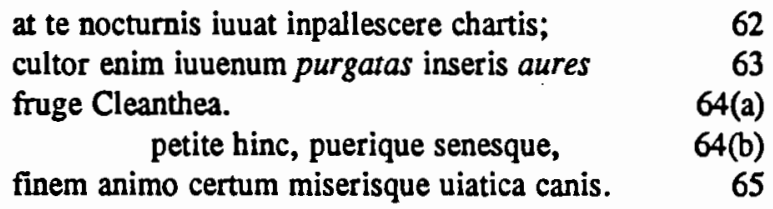

"But you delight in growing pale over nightly study, you cultivate the minds of the young and sow the seed of Cleanthes in their well-cleansed ears.

Seek thence, both young and old, a fixed aim for your spirit and travelling provisions for wretched old age."

I do not agree with Witke (1970:95-98) that the reintroduction of Cornutus is clumsy and that Persius pictures himself representing to Cornutus how he would deliver a diatribe. Nor is Harvey (1981:145) correct in saying that his reappearance is mildly surprising, "since he seemed to have been dispensed with after line 51, when Persius seemed to be moving onto a new argument, which in fact does not materialise until line $73^{\prime \prime}$.

Persius does have a definite reason for reintroducing his master (and this is indicated by Harvey himself): at as the first word of line 62 is emphatic not only by position, but its meaning, "on the other hand, on the contrary" (Lewis and Short, s.v. at II: "used to add an entirely opposite thought") serves to emphasise the contrast between the immoral and aimless ways of most men and the philosophical pursuits of Cornutus (nocturnis ... chartis, line 62).

The sunless days of ignorance and degeneracy (lines 60-61) are recalled by nocturnis - in contrast to the sunny days that Persius spent with Comutus earlier (line 41) - while inpallescere 7 in line 62 at first suggests the pallor of moral illness, the complexion of those who live in a dark atmosphere (line 61). Cornutus, however, grows pale nocturnis ... chartis, achieving self-improvement and acquiring knowledge through study, and not nocturnis conuiuiis or stupris as some of the non-philosphers do.8 The contrast between

6 For the metaphor in these lines see Anderson 1966:411-413; Bowman 1972:98-99; Raschke 1976:42-45.

7 For the continuing image of pallor in this satire, see Bowman 1972:97-98.

8 That Comutus' means of achieving self-improvement and acquiring knowledge, i.e. growing pale with study, is regarded as desirable, is attested by Hor. Epist. 1.2.34-35, Sen. Epist. 8.1 and Plin. Epist. 3.5.8. 
him and the non-philosopher is accentuated by the emphasis on chartis being not only the last word of the line, but also part of the split phrase nocturnis (adjective) iuuat inpallescere (verb) chartis (noun). Furthermore, it has to be noted that after nocturnis, which evokes associations of debauchery after what is said in the previous lines (especially in lines 56-58), the placing of chartis at the end comes as a surprise. This gives added force to the recommendation of Cornutus' way of life.9

Moreover, Cornutus' short reappearance gives Persius yet another opportunity to acknowledge the source of his Stoic training and to pay homage to the scholarship and wisdom of his guide and friend. By doing so, Persius actually refers back to two preceding sections (lines 14-16 and 36-44) in order to emphasise the necessity of philosophy for moral freedom; but even more so, these lines are an important reminder that Persius himself is a philosopher and it is as a philosopher that he will embark on the theme of Stoic freedom.

Cornutus is described as a farmer whose fields are the ears of the young, which he clears of the weeds of error and sows with the seeds of Stoic philosophy (lines 63-64a) (Morford 1984:59). The metaphor taken from agriculture is introduced by cultor and is carried on in purgatas, inseris and fruge.10 The literal meaning of cultor ... iuuenum, "a farmer of youth", may also mean "one who favours youth", cultor being used in its received extended sense ("a fosterer, supporter, tutor, teacher"/ "one who bestows care upon a thing") as well as literally ("cultivator, husbandman, planter") (Lewis and Short, s.v. cultor II A and I, and s.v. I b respectively). This would then recall Socrates' concern for the young implied in Socratico ... sinu, line 37 (Zietsman 1991:98), implying that as a philosopher Cornutus has the same degree of care for the youth as Socrates had.

Apart from purgatas being primarily an agricultural term denoting the clearing away of weeds prior to cultivation (Ovid Pont. 1.8.59), it also suggests normal ear-cleansing (as in line 86, aurem mordaci lotus aceto and Hor. Epist. 1.1.7, est mihi purgatam crebro qui personet aurem).

The phrase inseris aures / fruge (lines 63-64) is an unusual construction instead of the more ordinary inseris auribus frugem (Harvey 1981:146; Pretor 1907:70) and is also an unusual combination for although fruge generally means "grain or seed for eating" (Conington 1874:94, see also Lewis and Short, s.v. frux I) it here means "grain for seed" in combination with inseris which is strictly "to sow or plant in, to ingraft" (Lewis and Short, s.v. insero I). The metaphorical use of the noun in the phrase fruge Cleanthea (64) is however not uncommon, as for example in Hor. A.P. 341, centuriae seniorum agitant experta frugis.

The mention of Stoicism as a necessary prerequisite for a life that is morally free in lines 14-16 and 36-44 is repeated here in fruge Cleanthea (line 64). Cleanthes was the pupil of Zeno and teacher of Chrysippus and is here used as a representative of Stoicism (as Socratico ... sinu in line 37; see also Juv. 2.7, et iubet archetypos pluteum seruare Cleanthas); fruge should therefore be understood as doctrina, philosophia (Bo 1969:96). As a result of these references purgatas ... aures (line 63) gains an added meaning and

9 For the pallor (real or feigned) of study, see prol. 4, 1.26, 3.85 as well as Quint. 7.10.14 and Juv. 7.97.

10 Bo 1969:95 ad cultor: propr. uocabulum agreste, quod imaginem inducit totam ab agricultura desumptam; nam agricola ante quam serat, agrum purgat. See also Cic. Tusc. 2.5.13, cultura animi philosophia est; haec extrahit uitia radicitus et praeparat animos ad satus accipiendos ... et... serit quae adulta fructus uberrimos ferant. 
thus comes to denote receptiveness, since the ears are said to be cleansed or prepared to receive instruction in philosophy (fruge Cleanthea).

The sense of lines 63-64(a) is therefore that just as the farmer clears away the weeds before sowing the seeds, Cornutus cleanses the ears of youth from vices through his instruction and thereby educates them by the doctrine of Stoic philosophy. (So the scholiast. See also Hor. Epist. 1.1.39-40, nemo adeo ferus est ut non mitescere possit, / si modo culturae patientem commodet aurem.)

Only now does Persius address his audience directly, although he still refrains from singling out the individual reader, and he encourages mankind at large to pursue Stoicism:11 petite hinc, puerique senesque / finem animo certum miserisque uiatica canis, lines $64(\mathrm{~b})-65$. The language and thought recall Hor. Epist. 1.2.56, certum uoto pete finem; in both passages petere signifies not "to aim at", but "to procure" (Conington 1874:94). By addressing youth as well as old men, Persius makes it clear that men of all ages may benefit from philosophy.12 Bo (1969:96) adds an important explanation: quamquam iam prima pueritia discendum est (cf. Quint. 1.1.4; $1.5 \mathrm{sq} . ; 10,32$ ), tamen, ut Sen. Epist. 76.3 dicit, "tamdiu discendum est, quamdiu nescias: si prouerbio credimus, quandiu uiuas ... etiam seni discendum est".

According to Persius fruge Cleanthea is the source of wisdom for the journey of life for young and old alike. By implication the Stoic teaching of Cornutus will justify his own moral teaching which differs greatly in aim from the goals of the great majority of men (lines 52-61).

The poet ends his exhortation with a highly compressed thought: miseris ... uiatica canis (line 65) is in contrast to iam seri uitam ingemuere relictam (line 61). It is for the miseries of old age (canis is, of course, metonymy for senectuti) that the provision of philosophy is required (see Diog. Laert. 1.88 and 5.21), just as it is in decay that the evil of a bad life is felt (lines 58-61) (Conington 1874:94). Furthermore, his exhortation is also ambiguous (Harvey 1981:146): Stoicism is not only a comfort for the miseries of old age, but also helps the old to face the prospect of death which is the final destination of life's journey.13

Persius' discussion of Stoic freedom begins in line 73. The diatribe falls into two broad sections of roughly equal length. In the first (lines 73-131) the general theme of liberty is set forth and the falsity of the usual definition of freedom is established. In the second (lines 132-188) a series of examples is given to illustrate the theme of the first part.

The first part revolves round the definition of liberty. To most people it is the opposite of slavery in the physical and legal sense, and Persius illustrates the common view with a vigorous account of the manumission of the slave Dama and his sudden transformation into Marcus, a respectable Roman citizen (lines 73-82). This transformation is what people call real freedom.

"All right, then", replies an interlocutor (lines 83-85), "what about the man who lives just as he likes? Isn't he truly free?" The interlocutor is using the Stoics' own words, for they

11 Witke 1970:95: hinc, "from the Stoa"; Bo 1969:96: ex philosophia (also Jahn and the scholiast).

12 See for example Sen. Epist. 76.1-3 and Hor. Epist. 1.1.26, aeque neglecrum pueris senibusque nocebit.

13 For the transferred use of uiaticum, Harvey quotes Cic. De Sen. 66, potest enim quicquam esse absurdius quam, quo uiae minus restet, eo plus uiasici quaerere? 
said that "freedom was to live as one wished", with the necessary premise (here ignored by the interlocutor) that wishes are based on knowledge. Therefore knowledge of what is right must precede right exercise of the will. It follows that only he who knows what is right (that is, the wise man) is free to make right choices. The ordinary man (represented here by the interlocutor) thinks he has freedom of choice and is therefore more free than the early Roman hero Brutus, who drove out the tyrants (lines 84-85).

However, even the reference to the father of Roman freedom, Brutus, does not persuade the Stoic (lines 85b-87) to accept the interlocutor's claim to civil freedom and he denies the validity of the interlocutor's premise: the man who enjoys civil freedom does not automatically possess true libertas:

\[ \begin{array}{l}\text { 'mendose colligis' inquit } \\ \text { Stoicus hic aurem mordaci lotus aceto, }\end{array} \]
'hoc relicum accipio, "licet" illud et "ut uolo" tolle.' 87

"'You make the wrong deduction', says the Stoic at this point, his
ears well-washed with biting vinegar. 'I accept the rest, but erase
that I may and as I wish'."

Persius' objections to licet and ut uolo illustrate his argument that it does not necessarily constitute true freedom to "do as you may" or to "do as you like". Later in the satire (lines 132 onwards) it will become clear that he is not really free to do as he wishes, since his passions dictate to him what to do.

The emphatic periphrasis Stoicus hic (line 86) (and note that hic, "here, at this point/moment" is an adverb), refers to Persius himself (Harvey 1981:151) and anticipates his approach in criticising the interlocutor. Persius (i.e. the Stoic) regards himself as a surgeon and his satires as an operation on the diseased ears of mankind. It is with the cleansing of these diseased ears that Persius is concerned and the remedy, though fundamentally always the same, namely the truth, can be administered only by the satirist/philosopher.

The allusion here is that people who are quick to understand are said to have cleansed ears; those of slow apprehension are said to have blocked ears (Raschke 1976:42-44; LloydJones 1963:81-82). The Stoics had a special reputation for acuteness in detecting fallacies (see Cic. De Fat. 14 and De Fin. 3.3) and this use of vinegar (mordaci lotus aceto) may have been suggested by themselves or their admirers to account for their acuteness (Pretor 1907:73; Lackenbacher 1937:139).

I do not agree with Harvey (1981:151) who argues that aceto can best be understood as "wit" and that it is unlikely that Persius' phrase alludes to the inculcation of Stoicism. In line 64 fruge Cleanthea (a direct reference to Stoicism) is used metaphorically for "remedy" and it is my contention that aceto here implies the same: just as vinegar was a well-known remedy for ear diseases (Celsus De Med. 6.7.2f.), it is Stoicism that is here metaphorically used as the cleansing agent. Apart from Persius' own application of the metaphor of the cleansed ear in Satire 1, instruction is represented by a metaphor of earcleansing in Hor. Epist. 1.8.16, praeceptum auriculis hoc instillare memento. (This is admitted by Harvey 1981:151.) One has to bear in mind that the object of this satire is to underline the necessity of a conversion to Stoicism (through ratio and uirtutes) in order to obtain true moral freedom.

I agree with Pretor (1907:73) who interprets line 87 as follows: "The mere fact that you are a living creature I admit: the inference contained in licet and ut uolo I altogether deny." 
The point of his argument is that relicum (for which he reads reliqua) should not be understood to mean the whole of the major premise in the adversary's syllogism (i.e., that a free man is able to live as he wishes), but only to mean the words licet and ut uolo. This dissection of the adversary's argument word by word seems to be more in keeping with the character of the Stoic than the refutation involved in the ordinary explanation of the line. To deny the minor premise and conclusion of the syllogism in toto while admitting the proposition on which it is based, appears to be unsuited to the Stoic. Pretor continues to explain his argument as follows:

"I admit (says the Stoic) the major premise and conclusion of the syllogism. But the words you repeat from the major premise to form your minor premise, licet (mihi) ut uolo, do not bear the same meaning in this special case as in the general. The real Stoic formula always has in mind a man whose wishes are such as can be permitted, and a man with these wishes is permitted to live as he wishes and is therefore freer than Brutus. But your nature is not cultivated and educated: an outward change only has passed over you. You therefore cannot be permitted to live as you wish."

In lines 85(b)-87 Persius therefore proves that the interlocutor's premise that he is free, is wrong: the interlocutor needs the cure provided by Stoicism (mordaci ... aceto, line 86).

I have said earlier that the metaphor of the cleansed ear would feature prominently in Satire 5 as a result of the composition of the satire. It is important to indicate at this stage that lines $62-65$ form a pivotal point for the whole of the satire.

In the broad outline of the satire I have indicated that the satire consists of five distinct sections, or units as I prefer to call them:

Unit 1 is the explanation of the satirist's poetic principles: he rejects the slavery of his contemporaries to traditional themes and style.

Unit 2 explains the poet's philosophical foundations: when he had freedom of choice, he chose Cornutus as his example and learned from him the principles of Stoicism.

Unit 3 argues that other professions and walks of life lead to disaster and sorrow: Persius invites his audience to change their way of life and outlook now, and follow the doctrines of Cornutus.

Unit 4 illustrates that only the wise man is free and that philosophy is the only way to true moral freedom instead of slavery.

Unit 5 proves that refusal to change one's attitude and way of life leads to slavery because of one's passions.

Persius' rejection of the themes and style used by contemporary poets and his dismissal of their slavery to the traditional genres of epic and tragedy under the influence of a Greek Muse in Unit 1 is echoed in Unit 5 (see Diagram 1) by his dismissal of those who deem themselves free but are in actual fact slaves to their own passions. The examples of moral slavery in Unit 5 are an extension of Persius' intention to "scrape pallid morals" voiced by Cornutus in line 15: pallentis radere mores. 
In Unit 2 the poet had the chance to choose between freedom and moral slavery. By choosing Cornutus as his adoptive father and moral example, he chose to be educated in the principles of Stoicism. That these principles are a necessary prerequisite for true freedom is expounded in Unit 4 which is therefore an extension of Unit 2: the only way to true freedom instead of moral slavery is through Stoicism.

As a result of this circular construction Unit 3 is emphasised as the pivotal point of the satire, underlining the necessity of not delaying in following the doctrines of Cornutus, or, in other words, the principles of Stoicism.

\section{Diagram 1}

The relationship between the units can be represented as follows:

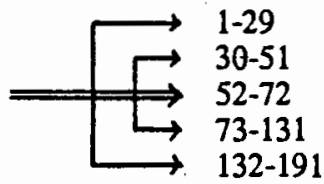
slavery to traditional genre and style option to choose between freedom and slavery follow the doctrines of Cornutus the way to true freedom instead of slavery slavery to uitia

Unit 3 itself forms a clear circular construction: the variety of human pursuits and the futility thereof (lines 52-61) is contrasted with Persius' exhortation to his audience to change their way of life (lines 66-72). The solution for this problem lies in lines 62-65, expounding as a means to make life worthwhile:

\section{Diagram 2}

Summary of the structure of Unit 3: lines 52-72

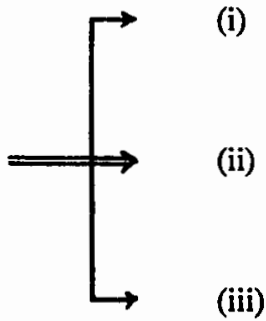

52-61 There are many different ways of spending one's life but they all result, in old age, in a sense of futility.

62-65 The element which will give meaning to life and which will make life worthwhile is the frux Cleanthea taught by Cornutus.

66-72 It is therefore advisable to change your way of life, your approach to life, and change it immediately, not tomorrow.

Furthermore, in Unit 3 the importance of the need for Stoic teaching is clearly brought out by the construction of lines 62-65 which consists of both a linear and circular composition (see Diagram 3). Firstly, the linear composition elucidates three aspects of Cornutus' method of instruction namely that

(a) he spends his nights (nocturnis) growing pale (inpallescere) by studying (chartis) (line 62), so that

(b) he can instruct receptive youth (aures) with the precepts of Stoicism (fruge Cleanthea) like a farmer (cultor) who sows the seeds (inseris) in a land cleared of weeds (purgatas) (lines 63-64a). This leads up to the important exhortation that 
(c) both young and old (puerique senesque) need to learn from Stoicism (hinc) how to provide comfort (uiatica) for the miseries of old age (miserisque ... canis) (lines 64b-65).

Secondly, the linear composition is complemented by an intricate circular composition. The reason for Cornutus' nightly study (a) is explained by (b) - Cornutus studies so that he can teach youth the principles of Stoicism. The exhortation in (c) continues the theme of philosophical training in (b) in a reversed manner, for hinc refers back to fruge Cleanthea. The result is that both (a) and (c) respectively draw attention to (b) as the focal point of lines 62-65. At the same time, however, (a) is linked to (c): the implication is that puerique senesque will also benefit from nightly study, for nocturnis ... inpallescere chartis (and not conuiuiis of stupris) is the only way by which to procure a knowledge of Stoicism - (b).

\section{Diagram 3}

The structure of lines 62-65 can therefore be represented as follows:

\section{Linear Circular}

$$
\downarrow \square\left[\begin{array}{lll}
\text { (a) } 62: & \text { Cornutus spends his nights studying. } \\
\text { (b) } 63-64(a): & \begin{array}{l}
\text { He instructs youth with the precepts of } \\
\text { Stoicism. }
\end{array} \\
\text { (c) } 64(\mathrm{~b})-65: & \begin{array}{l}
\text { It is from Stoicism that young and old can } \\
\text { make provision for old age. }
\end{array}
\end{array}\right.
$$

To conclude: It therefore seems that the structural unity of the satire constitutes a programme for Persius' poetry, explaining his themes and above all the reason for his specific approach to satire. Although Unit 3 does not convey the main theme of the satire, the whole satire as an entity revolves around lines 52-72, which constitute the motivation for Persius' satiric writings: the frux Cleanthea, sown into receptive ears (purgatas ... aures, line 63) gave him the freedom to write what he does write and as he does write; it is philosophy which gives meaning to his work, and philosophy can give meaning to the lives and work of all who follow the doctrines of Cornutus (petite hinc ... / finem animo certum miserisque uiatica canis, lines 64-65).

Thus Persius, as a poet who has the free mastery of his medium and as a human being who is free to make correct moral choices, has achieved freedom through the rigorous discipline of Stoic training (Mortord 1984:54): he, indeed, is Stoicus ... aurem mordaci lotus aceto (line 86).

\section{BIBLIOGRAPHY}

Bo, D. 1969. A. Persi Flacci saturarum liber. Torino: Paravia.

Bowman, R.S. 1972. The treatment of Stoic paradoxes by Cicero, Horace and Persius. Dissertation: University of North Carolina.

Bramble, J.C. 1974. Persius and the programmatic satire: a study in form and imagery. Cambridge: University Press.

Clausen, W.V. 1959. A. Persi Flacci et D. Iuni Iuvenalis saturae. Oxford: Clarendon (repr. 1968). 
Conington, J. \& Nettleship, H. 1874. The satires of A. Persius Flaccus. Oxford: Clarendon (2nd ed.).

Harvey, R.A. 1981. A commentary on Persius. Leiden: Brill.

Lackenbacher, H. 1937. "Persius und die Heilkunde." WS 55, 130-141.

Lee, G. \& Barr, W. 1987. The Satires of Persius. Liverpool: Cairns.

Lloyd-Jones, H. 1963. "The seal of Posidippus." JHS 83, 75-99.

Morford, M. 1984. Persius. Boston: Twayne.

Pretor, A. 1907. A Persii Flacci satirarum liber. Cambridge: Bell.

Raschke, W.J. 1976. Literary and historical studies in the satires of Lucilius and Persius. Dissertation: State University of New York.

Reckford, K.J. 1962. "Studies in Persius." Hermes 90, 476-504.

Warmington, E.H. 1962. Remains of Old Latin. London: Heinemann.

Witke, C. 1970. Latin satire: the structure of persuasion. Leiden: Brill.

Zietsman, J.C. 1991. "Persius, Saturn and Jupiter." Akroterion 36, 94-103. 